\title{
Suitability of Epstein-Barr virus-based episomal vectors for expression of cytokine genes in human lymphoma cells
}

\author{
S Mücke ${ }^{1}$, A Polack ${ }^{2}$, M Pawlita ${ }^{3}$, D Zehnpfennig ${ }^{2}, \mathrm{~N} \mathrm{Massoudi}^{1}$, H Bohlen ${ }^{1}$, W Doerfler ${ }^{4}$, \\ G Bornkamm², V Diehl ${ }^{1}$ and J Wolf ${ }^{1}$ \\ ${ }^{1}$ University of Cologne, Department of Internal Medicine I; ${ }^{2}$ Institute of Clinical Molecularbiology and Tumorgenetics, Munich; \\ ${ }^{3}$ Research Programm Applied Tumor Virology, Deutsches Krebsforschungszentrum, Heidelberg; and ${ }^{4}$ University of Cologne Institute \\ for Genetics, Cologne, Germany
}

Plasmids carrying the Epstein-Barr virus (EBV) latent gene EBNA1 and the EBV latent origin of replication (oriP) stay in transfected human cells as autonomously replicating extrachromosomal genetic units. They thus might represent a suitable tool for cytokine gene introduction into human tumor cells with the prospect of therapeutic antitumor vaccination. The aim of this study was to analyze whether such plasmids permit stable and efficient expression of cytokine genes in human non-Hodgkin lymphoma cells. We tested physical stability and expression levels of plasmids carrying EBNA1 and oriP for episomal maintenance, immunoglobulin light chain enhancer elements for augmentation of expression, and cytokine or marker genes after introduction into human NHL cell lines in vitro and in vivo after inoculation into nude mice. Data obtained with these EBV-based vectors were compared with another plasmid, not carrying EBNA1 and oriP. cDNAs coding for GM-CSF, IL6, TNF $\alpha$, the chloramphenicolacetyltransferase (CAT) and the $\beta$-galactosidase (lacZ) gene were transfected into the EBV-positive Burkitt's lymphoma cell line $B L 60$ and the EBV-negative $B$ cell lymphoma cell line BJA-B. EBV-derived vectors permitted a high, host cell independent transfection efficiency and high and host cell independent levels of expression. After removal of the selection pressure (hygromycin B) cytokine expression could be detected for several weeks in vitro and in vivo but, however, declined continuously. These experiments suggest that episomal BC-derived vectors represent an effective tool for cytokine gene transfer in human lymphoma cells.

Keywords: cytokine gene transfection; episomally replicating plasmids; EBV latent origin of replication; malignant lymphoma

\section{Introduction}

Induction of an antitumor host response by vaccination with genetically modified, cytokine secreting autologous tumor cells has been demonstrated in several murine tumor models. In these studies mice were vaccinated, for instance, with interferon gamma (IFN $\gamma$ )-transduced neuroblastoma cells, ${ }^{1}$ interleukin 2 (IL2)-transduced fibrosarcoma cells ${ }^{2}$ or IL2-transduced colon carcinoma cells. ${ }^{3}$ Other vaccination approaches included transduction of malignant cells with cDNA coding for granulocyte-macrophage colony-stimulating factor (GM-CSF), IL4, IL7, IL8 or tumor necrosis factor alpha $(\mathrm{TNF} \alpha){ }^{4}$ Cytokine expression in tumor cells was shown to activate MHC-restricted cytotoxic T cells, lymphokine-activated killer (LAK) cells, natural killer (NK) cells and macrophages. ${ }^{5}$ These promising animal studies have now initiated several clinical phase I/II trials using solid

Correspondence: J Wolf, Department of Internal Medicine I, University of Cologne, LFI, Ebene 5, Raum 310, 50924 Cologne, Germany Received 6 September 1996; accepted 18 October 1996 tumor cells transduced with retroviral constructs expressing human cytokine genes. ${ }^{6}$

Malignant lymphomas also represent attractive candidates for cytokine transfer-mediated immune therapy. Immunoglobulin (Ig) gene idiotypes expressed on B lymphoma cells are tumor-specific antigens and thus represent individual targets for specific immune therapy. In mice a humoral as well as a cellular immune response have been demonstrated against Ig idiotypes. Furthermore, idiotype immunization led to tumor regression of murine B cell lymphoma. ${ }^{7}$ This effect could be augmented by systemic administration of IL2 and IFN $\gamma .^{8}$ In the murine model the idiotypes themselves have only a weak immunogenic potential. A pronounced augmentation of idiotype immunogenicity, was achieved by use of idiotype/GM-CSF fusion proteins. ${ }^{9}$ Yet, no data exist with regard to augmentation of an immune response following cytokine gene transfection into human lymphoma cells.

The most widely used gene transfer systems are replication-incompetent retroviruses permitting a high transduction efficiency. Retroviral gene transfer, however, involves some still unsolved problems. Owing to integration of the vector into the host cell genome, expression 
of transduced genes may vary with the integration site and cell type. In addition, insertional mutagenesis represents a possible hazard. ${ }^{10}$ Thus, alternative viral and nonviral gene delivery and expression systems are being explored.

Recently, infectious EBV-based vectors (mini-EBVs) were engineered to transfer genes into human B cells. ${ }^{11}$ These infectious mini-EBVs carried cis-acting elements of EBV necessary for episomal maintenance, amplification and packaging of the vector, not however, any of the known latent EBV genes associated with transformation. Successful infection of B lymphoblastoid cells from a Fanconi anemia group $C(F A-C)$ patient with a mini-EBV vector expressing the normal FACC cDNA could be demonstrated. Compared with retrovirus-mediated gene transfer, these mini-EBVs had the advantage of replicating episomally in the target cells, thus avoiding the possible hazards of integration into the host cell genome. However, there might still be concerns about the incalculable hazards of working with infectious particles. This concern might especially hold true for the cloning of cytokine genes into such vectors, which then might exert pleiotropic growth promoting and growth inhibiting effects.

For ex vivo cytokine transfer in lymphoma (and other tumor) cells it would be desirable to use potent expression vectors, which have the advantage of episomal replication, but do not represent infectious particles. In this study we have tested cytokine gene introduction and expression in human lymphoma cell lines using plasmids containing the Epstein-Barr virus nuclear antigen 1 (EBNA1) gene and the viral latent origin of replication (oriP) permitting the episomal state of these plasmids and in addition immunoglobulin kappa light chain enhancer elements for augmentation of expression. Results with these episomal vectors were systematically compared with results obtained with a vector not carrying these EBV and Ig kappa light chain gene-derived genomic elements.

\section{Results}

\section{Construction of expression vectors}

The expression vectors pKEX-CAT, pKEX-TNF $\alpha$ and pKEX-IL6 were obtained by cloning CDNAs for the CAT gene, TNF $\alpha$ and IL6 into the pKEX-2XR-plasmid. The expression vectors BC219-IL6, BC219-TNF $\alpha$ and BC219GM-CSF were obtained by cloning the cDNAs into the plasmid BC219, which replicates episomally after transfection due to the presence of the EBV nuclear antigen 1 (EBNA1) and the EBV latent origin of replication (oriP). Table 1 summarizes the vectors constructed. Figure 1

Table 1 Vectors constructed for CAT, lacZ and cytokine expression

\begin{tabular}{ll}
$\begin{array}{l}\text { Nonepisomal vectors } \\
(p K E X-2 X R \text {-derived })^{a}\end{array}$ & \multicolumn{1}{c}{$\begin{array}{c}\text { Episomal vectors } \\
(\text { BC219-derived })^{a}\end{array}$} \\
\hline pKEX-CAT & BC230a (=BC219-CAT) \\
pKEX-IL6 & BC219-IL6 \\
pKEX-TNF $\alpha$ & BC219-TNF $\alpha$ \\
& BC219-GM-CSF \\
& BC219-DZ17 (=lacZ)
\end{tabular}

${ }^{a}$ For detailed map see Figure $1 \mathrm{a}$ and $\mathrm{b}$ shows the maps of the basic vectors. For detailed cloning strategy see Materials and methods.

\section{Transfection of BL60-P7 and BJA-B cells with pKEX-} $2 X R$ - and BC219-derived expression vectors

pKEX-CAT, pKEX-IL6 and pKEX-TNF $\alpha$ were transfected into the Burkitt's lymphoma cell line BL60-P7 and the EBV-negative B cell lymphoma cell line BJA-B using electroporation. The number of growing, hygromycin Bresistant clones was determined 3 weeks after electroporation. The stable transfection efficiency was defined as the ratio of hygromycin B-resistant clones to viable cells after electroporation. For each cell line and vector type transfection efficiencies were rather similiar, regardless of the given insert. Using the pKEX constructs, average transfection efficiency was approximately 1 to $7.1 \times 10^{4}$ for BJA-B cells and 1 to $2.5 \times 10^{6}$ for BL60-P7 cells.

The BC219-IL6, BC219-TNF $\alpha, B C 219-G M-C S F, B C 230 a$ $(=\mathrm{BC} 219-\mathrm{CAT})$ and BC-DZ17 (=BC219-lacZ) were transfected into BL60-P7 and BJA-B cells by the same procedure. For these vectors the average transfection efficiency was approximately 1 to $2.4 \times 10^{4}$ for BJA-B cells and 1 to $2.7 \times 10^{4}$ for BL60-P7 cells. Thus, by comparison with pKEX-2XR, BC219-derived vectors show a 3.2-fold higher transfection efficiency in BJA-B cells and a 92-fold higher transfection efficiency in BL60-P7 cells (see also Table 2).

Southern blotting was performed to determine the physical state of the transfected pKEX-plasmids in hygromycin B-resistant BL60-P7 and BJA-B transfectants. Cellular DNA from four representative BL60-pKEX-CAT transfectants was digested with BamHI and hybridized with the ${ }^{32}$ P-labeled pKEX-CAT DNA (Figure 2a). BamHI digestion of pKEX-CAT plasmid results in two fragments of 6.0 and $1.6 \mathrm{~kb}$ length, respectively. Thus, after integration of the pKEX-CAT plasmid into the BL60 genome in Southern blot analysis, three BamHI fragments are expected. The total length of these fragments should be at least $7.6 \mathrm{~kb}$ (plus the length of adjacent cellular fragments). In all four BL60-pKEX-CAT clones three fragments were detected. The upper band of $5.8 \mathrm{~kb}$ size is due to hybridization of the pKEX-CAT plasmid to the pSV2neo-plasmid ${ }^{12}$ which had been transfected into this cell line previously. ${ }^{13}$ The additional two bands which differ in size in all transfectants are interpreted to represent integrated pKEX-CAT sequences joined to BL60P7 sequences. In all four clones the detected pKEX-CAT fragments are shorter than the total length of $7.6 \mathrm{~kb}$ of the pKEX-CAT plasmid. This may be due to a partial deletion of the plasmid during the integration process into the cellular genome. This might underlie the nonexpression of CAT protein of these transfectants (see below) since promoter-CAT gene sequences could be affected by the deletion.

Southern blot analysis was also performed to determine the physical state of the transfected vectors in the BJA-B and BL60-P7-BC transfectants. Figure $2 \mathrm{~b}$ shows DNA of three BJA-B-BC230a and three BL60-BC230a transfectants which were $\mathrm{BamHI}$ digested and hybridized with the ${ }^{32}$ P-labeled BC230a plasmid. In all BJA-B and BL60 clones exclusively the expected two fragments of 12.9 and $2.0 \mathrm{~kb}$, respectively, were found to be generated by digestion of the $\mathrm{BC} 230 \mathrm{a}$ plasmid with $\mathrm{BamHI}$ demonstrating the episomal state of the vector. The additional band in all BL60-P7 clones of $5.8 \mathrm{~kb}$ is generated from 


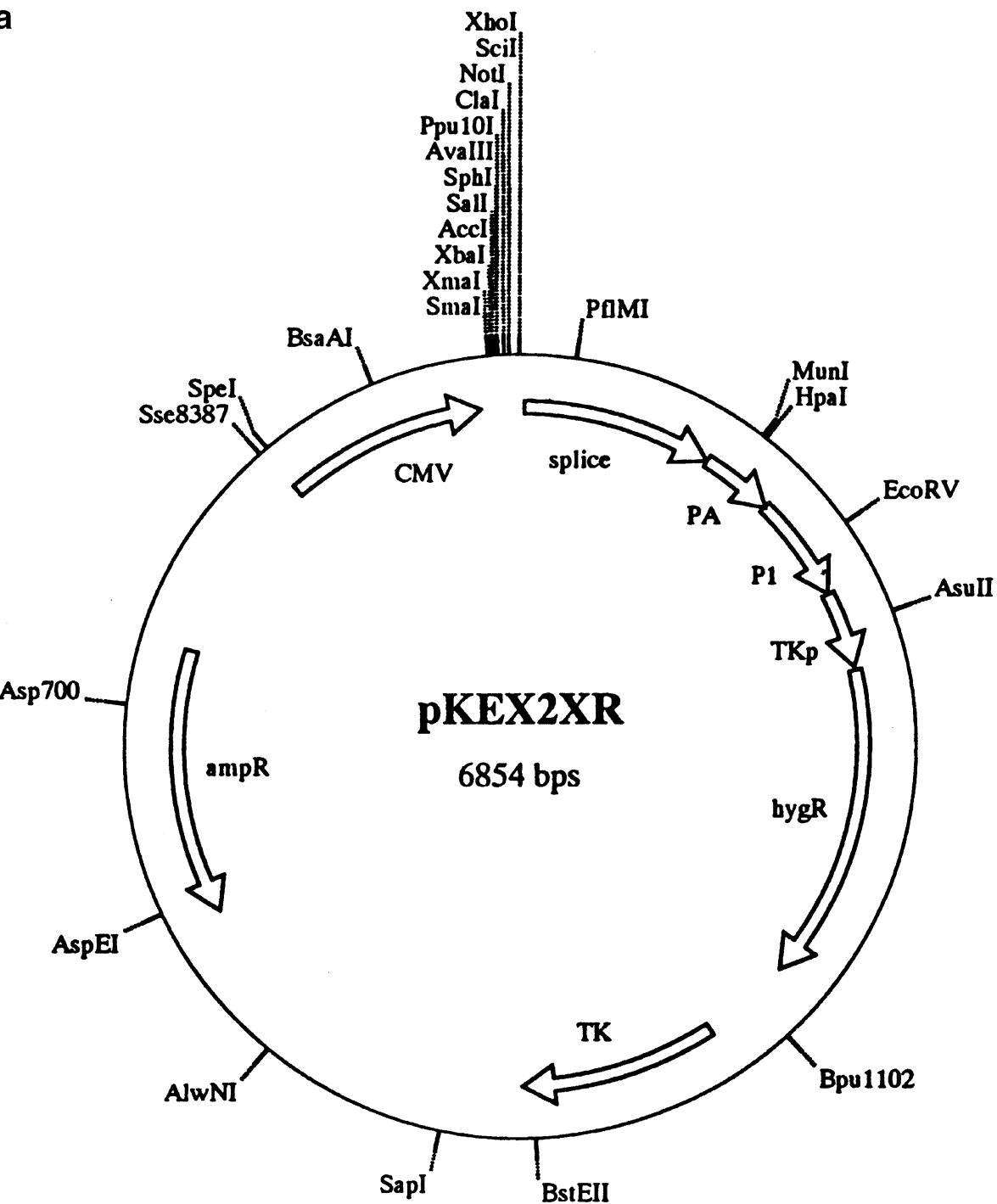

Figure 1 (a) Map of pKEX-2XR. CMV: human cytomegalovirus immediate-early promoter-enhancer element; splice and PA: simian virus 40 (SV40)derived small T-antigen splice and late gene polyadenylation signal; TKp: thymidine kinase promoter; hygR: hygromycin B resistance gene; ampR: ampicilline resistance gene.

cross-hybridization of the $\mathrm{BC} 230 \mathrm{a}$ probe to the pSV2neoplasmid (see above). Figure 2c shows Southern blot analysis of four BJA-B and BL60-BC-TNF $\alpha$ transfectants which were hybridized with a ${ }^{32} \mathrm{P}-$ labeled BC219 probe. Again an identical hybridization pattern is found in all clones, namely two bands of 12.9 and $2.0 \mathrm{~kb}$ which represent the $\mathrm{Bam} \mathrm{HI}$ digested $\mathrm{BC}-\mathrm{TNF} \alpha$ plasmid. The $5.8 \mathrm{~kb}$ fragment in the BL60-clones is again generated by crosshybridization with the pSV2neo-plasmid.

\section{Expression of cytokines and CAT protein in BJA-B and BL60-P7 transfectants}

For each pKEX-2XR-derived expression vector, namely pKEX-CAT, pKEX-IL6 and pKEX-TNF $\alpha, 10$ stable BL60P7 and 10 stable BJA-B transfectants were isolated. After $24 \mathrm{~h}$ culture in fresh medium, the cytokine concentration of $1 \times 10^{6}$ exponentially growing cells $/ \mathrm{ml}$ culture medium and CAT protein in $50 \mu \mathrm{g}$ of total extracted cellular protein were measured. CAT expression of the BJA-B-pKEX-CAT clones reached from 90 to $2100 \mathrm{pg} / \mathrm{ul}$. Cytokine concentration was measured from 8 to 700 $\mathrm{pg} / \mathrm{ml}$ for the BJA-B-pKEX-IL6 and from 40 to 2050 $\mathrm{pg} / \mathrm{ml}$ for the BJA-B-pKEX-TNF $\alpha$ clones. In contrast, no expression could be found in the BL60-P7 cells stably transfected with pKEX-2XR-derived expression vectors (Table 3). Cytokine and CAT expression was also measured for BL60-P7 and BJA-B clones stably transfected with BC219-derived vectors. In 10 out of 10 BJA-B and BL60-P7 clones, respectively, high expression levels for each transfected gene were found. IL6 expression ranged between 900 and $1210 \mathrm{pg} / \mathrm{ml}, \mathrm{TNF} \alpha$ expression between 1350 and $1900 \mathrm{pg} / \mathrm{ml}, \mathrm{GM}-\mathrm{CSF}$ expression between 650 and $655 \mathrm{pg} / \mathrm{ml}$ and CAT protein expression between 3800 and $5100 \mathrm{pg} / \mathrm{ml}$ (Table 3).

Taken together these data demonstrate that transfection with pKEX-2XR-derived expression vectors leads to quite variable expression patterns differing considerably between transfected clones of the same cell line as well as in between the cell lines BJA-B and BL60-P7, with no detectable expression in the latter. In contrast, transfection with the BC219 vector leads to transfectants with quite similiar expression levels in all BJA-B and BL60-P7 


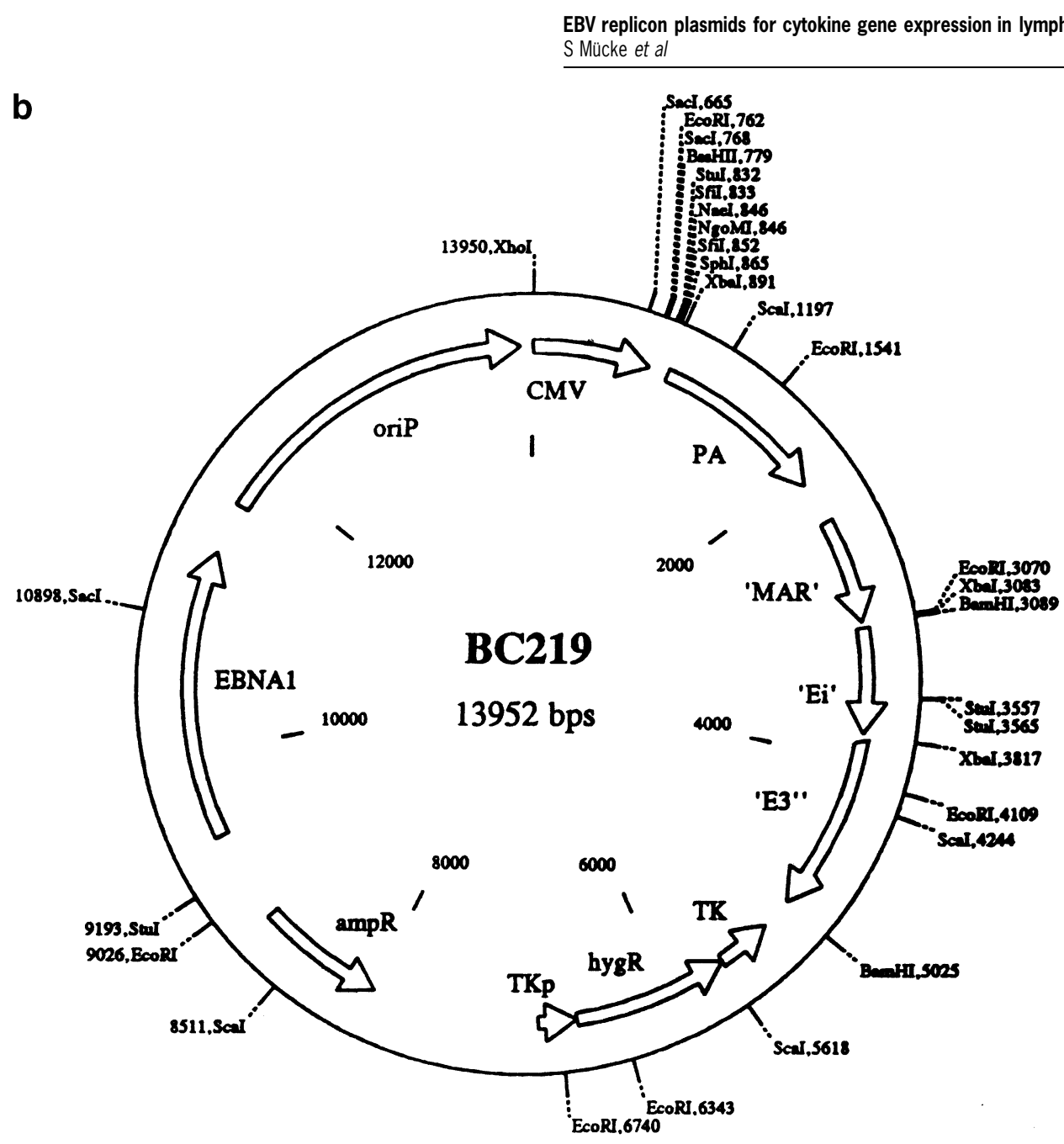

Figure 1 (b) Map of BC219. MAR: matrix attachment region; Ei: intron enhancer element; E3: 3'enhancer element of the human Ig kappa light chain gene locus; EBNA1: Epstein-Barr virus nuclear antigen 1 gene; oriP: Epstein-Barr virus latent origin of replication.

clones. In addition, the absolute amounts of cytokines or CAT protein were higher in all BJA-B and BL60-P7 clones transfected with BC219-derived vectors compared to pKEX-2XR-derived transfectants with the exception of BJA-B-pKEX-TNF $\alpha$ clones with expression levels comparable to those of BJA-B-BC-TNF $\alpha$ clones.

\section{LacZ expression in BL60-P7 and BJA-B transfectants}

To analyze the expression status of the episomal vectors in single cells, one clone of each BL60-P7 and BJA-B transfected with BC-DZ17, containing the lac Z gene, were stained for lac $Z$ expression in a $\beta$-gal-in situ assay. Blue staining of the cells indicates expression of the lac $Z$ gene. As shown in Figure 3a, about 50\% of the BL60-BC-DZ17 clone 1.3.5. expressed the lac $Z$ gene with a varying intensity. In BJA-B-BC-DZ17 clone 4.3.5. about $80 \%$ of the cells were positive for lac $Z$ expression (Figure $3 \mathrm{~b}$ ). The number of positive cells was constant in both clones over a cultivation period of 6 months after transfection using hygromycin B selection.

\section{No changes of endogenous cytokine expression in} BL60-P7 cells after transfection with BC219-derived vectors

Introduction of foreign DNA into eukaryotic cells may influence their endogenous gene expression pattern. To analyze whether transfection of BL60-P7 cells with BC219 vectors leads to altered cytokine expression, BL60-BC219 transfectants were examined for their endogenous cytokine expression using ELISA. Untransfected BL60-P7 cells did not express the cytokines IL6, IL8, IL10 and TNF $\alpha$. BL60-BC219 transfectant clones also did not express these cytokines (data not shown). Thus, transfection of BL60-P7 cells with $\mathrm{BC} 219$ vectors seems not to induce endogenous cytokine expression and the IL6 expression of BL60-BCIL6 and TNF $\alpha$ expression of BL60-BC-TNF $\alpha$ transfectants, respectively, is due to expression of the transfected BC219-derived vector.

Stability of expression of pKEX-2XR- and BC219derived expression vectors in vitro and in vivo

To analyze whether release of selection pressure leads to loss of the vectors transfected, one BJA-B-pKEX-TNF $\alpha$ clone and one BJA-B-pKEX-IL6 clone were cultivated without hygromycin B selection. TNF $\alpha$ and IL6 expression were measured over a period of 8 weeks in the supernatant of continuously proliferating cells. The BJA-B-pKEX-IL6 clone 1.8.6. expressed $250 \mathrm{pg} / \mathrm{ml} / 24 \mathrm{~h}$ IL6 4 weeks after transfection. No significant decrease of expression could be found in the culture without hygromycin B after 36 weeks when IL6 expression was still 210 $\mathrm{pg} / \mathrm{ml} / 24 \mathrm{~h}$. Similarly, TNF $\alpha$ expression of BJAB-pKEX- 
Table 2 Transfection efficiencies of pKEX-2XR and BC219 plasmids after electroporation of BL60 P7 and BJA-B cells

\begin{tabular}{|c|c|c|c|}
\hline Transfected cell line & $\begin{array}{l}\text { Viable cells seeded } \\
\text { after electroporation }\end{array}$ & $\begin{array}{l}\text { Number of stable } \\
\text { transfected clones }\end{array}$ & Transfection efficiency \\
\hline BJA-B-pKEX-2XR & $1.2 \times 10^{7}$ & 196 & $1 / 6 \times 10^{4}$ \\
\hline BJA-B-pKEX-IL6 & $9.5 \times 10^{6}$ & 101 & $1 / 9.3 \times 10^{3}$ \\
\hline BJA-B-pKEX-TNF & $1.1 \times 10^{7}$ & 178 & $1 / 6.1 \times 10^{4}$ \\
\hline BJA-B-pKEXCAT & $7.5 \times 10^{6}$ & 107 & $1 / 7.0 \times 10^{4}$ \\
\hline BL60-pKEX-2XR & $9.8 \times 10^{6}$ & 3 & $1 / 3.3 \times 10^{6}$ \\
\hline BL60-pKEX-IL6 & $5 \times 10^{6}$ & 2 & $1 / 2.5 \times 10^{6}$ \\
\hline BL60-pKE X-TNF & $7.5 \times 10^{6}$ & 3 & $1 / 2.5 \times 10^{6}$ \\
\hline BL60-pKEX-CAT & $9.6 \times 10^{6}$ & 5 & $1 / 1.9 \times 10^{6}$ \\
\hline BJA-B-BC219 & $1 \times 10^{7}$ & 800 & $1 / 1.3 \times 10^{4}$ \\
\hline BJA-B-BC-IL6 & $4.5 \times 10^{6}$ & 225 & $1 / 2.0 \times 10^{4}$ \\
\hline BJA-B-BC-TNF $\alpha$ & $8.4 \times 10^{6}$ & 210 & $1 / 1.0 \times 10^{4}$ \\
\hline BJA-B-BC-GM-CSF & $3.5 \times 10^{6}$ & 163 & $1 / 2.1 \times 10^{4}$ \\
\hline ВJA-B-BC230a & $1.1 \times 10^{6}$ & 135 & $1 / 8.1 \times 10^{3}$ \\
\hline BJA-B-BC-DZ17 & $5.4 \times 10^{6}$ & 432 & $1 / 1.3 \times 10^{4}$ \\
\hline BL60-BC219 & $6.8 \times 10^{6}$ & 338 & $1 / 2 \times 10^{4}$ \\
\hline BL60-BC-IL6 & $6.8 \times 10^{6}$ & 270 & $1 / 2.5 \times 10^{4}$ \\
\hline BL60-BC-TNF $\alpha$ & $1.3 \times 10^{7}$ & 990 & $1 / 1.3 \times 10^{4}$ \\
\hline BL60-BC-GM-CSF & $3 \times 10^{6}$ & 121 & $1 / 2.4 \times 10^{4}$ \\
\hline BL60-BC230a & $1.5 \times 10^{7}$ & 273 & $1 / 5.5 \times 10^{4}$ \\
\hline BL60-BC-DZ17 & $6.5 \times 10^{6}$ & 258 & $1 / 2.5 \times 10^{4}$ \\
\hline
\end{tabular}

TNF $\alpha$ clone 2.2.5 did not change significantly after release of selection pressure. Taken together these data demonstrate a stable cytokine expression reflecting the stable integration of pKEX-2XR-derived expression vectors in BJA-B transfectants without hygromycin B selection.

The stability of cytokine expression of BL60-BC-IL6 transfectants was examined. One BL60-BC-IL6 clone was cultivated in vitro over a period of 9 weeks with and without hygromycin B selection and IL6 expression was measured weekly in the supernatant of continuously proliferating cells using ELISA. While IL6 expression remained stable in BL60-BC-IL6 cells cultivated with hygromycin B selection over the whole period, BL60-BC-IL6 transfectants cultivated without hygromycin B showed a decrease of IL6 expression. After 9 weeks cells expressed only $12.5 \mathrm{pg} / \mathrm{ml}$ IL6 in comparison to $456.5 \mathrm{pg} / \mathrm{ml}$ in the first week (Table 4). A similar IL6 expression pattern was found for BL60-BC-IL6 transfectants in vivo. Four nu/nu mice were inoculated with $1 \times 10^{7}$ BL60-BC-IL6 cells in each flank. After 2, 4 and 6 weeks, mice were killed, tumor cells were recultivated and IL6 expression was measured after $24 \mathrm{~h}$. IL6 expression decreased from 212.6 $\mathrm{pg} / \mathrm{ml}$ after 2 weeks to $94.3 \mathrm{pg} / \mathrm{ml}$ after $5^{\frac{1}{2}}$ weeks (Table 5). These data demonstrate that under in vivo conditions, without selection pressure, cytokine expression can be achieved only transiently with BC-derived expression vectors.

\section{Discussion}

The attraction of modified viruses for gene therapy is mainly based on their capacity to infect a high percentage of cells in vitro and in vivo. Thus, retroviruses, adenoviruses, adeno-associated viruses (AAV), herpesviruses and others have been modified as vectors for introduc- tion of cDNAs in human tumor cells. ${ }^{14-19}$ However, the use of infectious viruses in gene therapy has also been described to be associated with disadvantages, eg insertional mutagenesis inducing secondary cancers, ${ }^{20}$ recombination events leading to pathogenic infectious agents, ${ }^{21}$ induction of an immune response against the viral vectors $^{22}$ and, last but not least, the complexity of the manufacturing procedures.

Noninfectious, plasmid-based expression vectors may circumvent several of these problems. These vectors can be introduced into the target cells, for instance by direct inoculation of the DNA (naked DNA approach), after mixture with polycationic lipids (liposome-mediated gene delivery) or by complexing with polycations such as poly-(L-lysine). ${ }^{23-27}$

As a rule such plasmid vectors persist in the majority as episomal elements and permit short-term gene expression. A minority of the transfected plasmids, however, become integrated by chance into the host cell genome. In contrast, plasmids containing the EBV latent protein EBNA1 and in addition the viral latent origin of replication (oriP) are stably maintained after transfection as autonomously replicating episomes. ${ }^{28}$ However, no data have been raised with regard to their long-term stability in vivo.

We were interested, whether such EBV-derived vectors might be suitable for cytokine gene expression in lymphoma cells with the prospect of vaccination therapy using cytokine-transfected lymphoma cells. Thus, we cloned the cDNAs for different human cytokines and for the marker genes CAT and lacZ into expression vectors carrying EBNA1, oriP and in addition human immunoglobulin kappa light chain enhancer elements (BC219derived plasmids). After transfection into a human EBVpositive and an EBV-negative lymphoma cell line we tested stable transfection efficiency, expression level and 
long-term expression in vitro and in vivo in a nude mouse model. The results were systematically compared with results obtained after transfection of plasmid vectors not carrying the EBV elements for episomal maintenance (pKEX-derived vectors) ${ }^{29}$ into the same cell lines.

The episomal EBNA1/oriP vectors permitted in general a higher transfection efficiency compared with the pKEX-derived vectors, ie about a three-fold elevated number of stably transfected clones for cell line BJA-B and about 90-fold augmented for the BL60 cell line. These results reflected the stable, cell line-independent episomal maintenance of the EBNA1/oriP vectors during selection of hygromycin B-resistant clones after transfection. This was confirmed by Southern blot analysis which demonstrated the episomal state of the vectors without any evidence of integration into the host cell genome. By comparison, the lower rate of stable transfected cells using the pKEX-derived vectors reflected loss of episomal plasmid DNA shortly after transfection and the longterm persistence exclusively of vector DNA integrated into the host cell genome, as also demonstrated by Southern blot analysis.

Expression analysis after transfection of the EBNA1/oriP vectors revealed high cytokine concentrations in the supernatant of proliferating cells and high levels of intracellular CAT protein, respectively, in BL60 as well as in BJA-B cells. With the exception of $\mathrm{TNF} \alpha$, expression levels were higher with EBNA1/oriP vectors compared with pKEX-derived vectors. Moreover, and also in contrast to pKEX-derived vectors, with the EBNA1/oriP vectors expression levels of a given cytokine differed only slightly between different transfected clones of the same cell line as well as between the two cell lines tested. This observation confirmed the absence of position effects on gene expression due to vector integration when using the EBNA1/oriP vectors.

In contrast to the BJA-B cell line, BL60 cells transfected with the pKEX vectors did not express cytokines or the CAT gene at all. This observation was surprising, since integration of the $\mathrm{pKEX}$ vectors in the genome of BJA-B was demonstrated by Southern blot analysis. In addition, expression of transfected genes in BL60 cells using a pKEX vector has already been described. ${ }^{30,31}$ Possibly the integration process led to destruction of the vector. This was suggested by the results of Southern blot analysis, where the addition of the length of the integrated vector fragments did not result in the length of the whole plasmid.

Maintenance of expression of the EBNA1/oriP vectors was also analyzed without hygromycin B selection pressure. In vitro as well as in nude mouse tumors, cytokine expression could be measured over several weeks but, however, declined continuously. In the 4th week after removing hygromycin B the expression level of IL6 was approximately $50 \%$ of the initial level, and after about 2 more weeks approximately $25 \%$. Thus, these vectors cannot be used for gene therapeutic strategies where longterm gene expression is essential, as for instance introduction of a multidrug resistance gene in hematopoietic stem cells or substitution of gene defects as in Gaucher's disease. However, for inducing an antitumor immune response by cytokine transfection of tumor cells they represent a suitable tool.

Recently, a vector has been described which also carries the EBV genomic elements EBNA1 and oriP to allow stable, non-integrative maintenance. In addition, this vector carried EBV elements necessary for packaging, thus representing an infectious particle (mini-EBV). ${ }^{11}$ The use of infectious particles includes risks difficult to estimate. Naturally, EBV infects B lymphocytes ${ }^{32}$ and epithelial cells. ${ }^{33}$ It has also been found in $\mathrm{T}$ lymphocytes of patients with chronic EBV infection, ${ }^{34}$ in parotid gland ducts $^{35}$ in hairy leukoplakia of the tongue ${ }^{36}$ and in smooth muscle tumors of immunosuppressed children. ${ }^{37}$ Thus, a wide spectrum of cells might be infected when using such mini-EBVs for gene therapy. In addition, since over $90 \%$ of the general population harbor the virus, recombination events might occur generating a recombinant EBV carrying the 'therapeutic' genes. Considering the pleiotropic growth stimulating and activating effects of cytokines the use of such mini-EBVs for cytokinemediated gene therapy might be dangerous.

In contrast, the vectors presented in this work, permit the introduction of cytokine genes in lymphoma cells as non-integrative, self-replicating, extrachromosomal genetic units. Thus, they avoid the hazards of integration into the host cell genome as well as those of using infectious particles. In addition, they are easy to handle and possess a high cloning capacity. Owing to their structural and functional similiarity to the EBV genome these vectors are expected to be functional also, when they contain multiple inserts. Thus, bi- or polycistronic vectors can be constructed, eg vectors containing the cytokine cDNA together with a suicide gene (HSVtk) and/or the cDNA encoding for the second signal molecule B7. To restrict the expression of these vectors after transfection the CMV promotor could be replaced through cell-type-specific promoters. The p1-myc promoter for example would lead to expression exclusively in B cells. ${ }^{38}$ Taken together, our experiments suggest that these BC219-derived vectors may represent an effective tool for cytokine gene transfer in human lymphoma cells.

\section{Materials and methods}

\section{Basic expression vectors}

Vector pKEX-2XR (Figure 1a) was described by Rittner et al. ${ }^{29}$ The $6.8 \mathrm{~kb}$ plasmid carries the human cytomegalovirus immediate-early (HCMV-IE) promoter-enhancer element, the simian virus 40 (SV40)-derived small T-antigen splice and late region polyadenylation signal and the hygromycin B resistance gene. Vector BC219 (Figure 1b) was described by Polack et al..$^{39}$ Briefly, the $13.9 \mathrm{~kb}$ plasmid carries the EBV latent origin of replication (oriP), and EBNA1 leading to episomal persistence of the plasmid in eucaryotic cells. Beside the HCMV-IE promoter-enhancer it carries additional enhancer elements for increase of expression, namely the matrix attachment region (MAR), the intron and the $3^{\prime}$ enhancer elements of the human Ig kappa light chain gene locus. ${ }^{39}$ BC230a contains the chloramphenicolacetyltransferase (CAT) gene as a SfiI fragment and BC-DZ17 contains the lacZ gene, cloned into the NaeI site of BC219.

\section{Construction of expression vectors}

cDNAs of the human cytokines IL6 and TNF $\alpha$ were purchased from the American Type Culture Collection (ATCC, Rockville, MD, USA). The CAT gene was kindly provided by $\mathrm{M}$ von Knebel-Döberitz (DKFZ Heidelberg, Germany). 
a

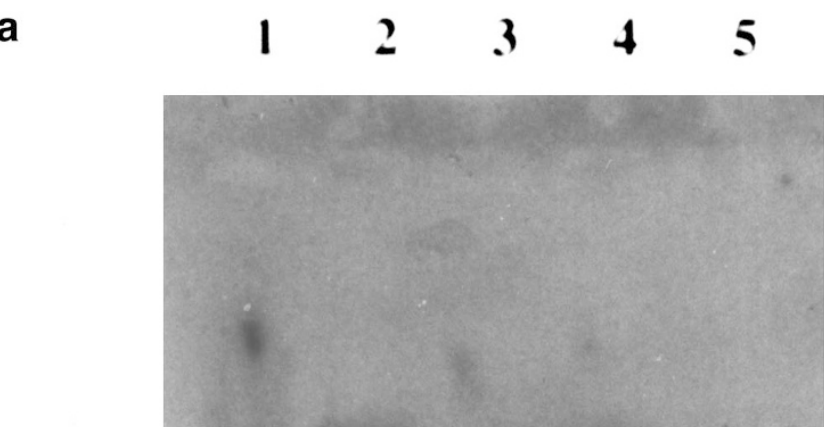

$5.8 \mathrm{~Kb}$

Standard cloning techniques were used as described.$^{40}$ For construction of pKEX-CAT the CAT coding sequence was isolated as a HincII fragment and cloned into the SmaI site of pKEX-2XR. For construction of pKEX-IL6 the IL6-cDNA was isolated as an EcoRI-HindIII fragment from the vector pGEMII-2. ${ }^{41}$ After blunt-end formation with the Klenow fragment of DNA polymerase I the fragment was inserted into the SmaI site of pKEX-2XR. For construction of pKEX$\mathrm{TNF} \alpha$ the TNF $\alpha$ cDNA was isolated as a PstI fragment of the vector $\mathrm{pE} 4,{ }^{42}$ cloned into the Bluescript vector $\mathrm{pBS}$ M13 KS (Stratagene, La Jolla, CA, USA), cut out as a XhoI-XbaI fragment and ligated to the XhoI-XbaI sites of pKEX-2XR. For cloning cytokine cDNAs into BC219, they were first cloned into $\mathrm{pBS}^{*}$, a variant of $\mathrm{pBS}$ M13 KS with a different polylinker site, namely SacI-SfiI-PstI-EcoRI-XbaI-HindIIIXhoI-BamHI-SfiI-KpnI. It was constructed to provide cytokine cDNAs with a SfiI site before cloning into BC219. BCIL6 was constructed from the EcoRI-HindIII-IL6 cDNA

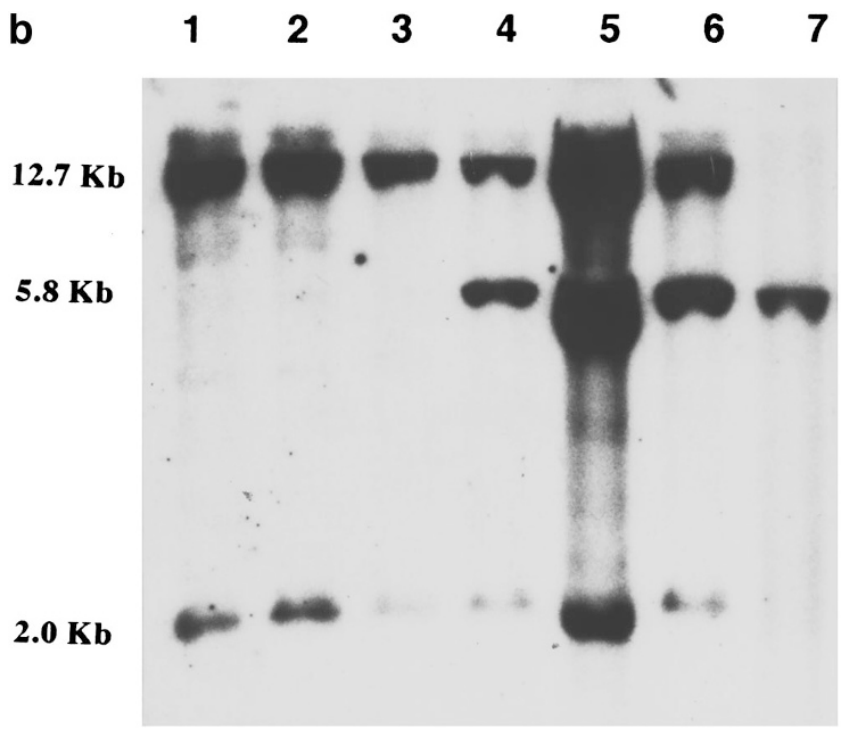

Figure 2 (a) Southern blot analysis of BL60-pKEX-CAT-transfectants Lane 1: BL60-pKEX-CAT clone 3.7.2.; lane 2: BL60-pKEX-CAT clone 3.6.7.; lane 3: BL60-pKEX-CAT clone 3.6.7.; lane 4: BL60-pKEX-CAT clone 3.6.2.; lane 5: BL60-P7. The genomic DNA of four BL60-pKEXCAT clones was BamHI digested, blotted and hybridized with a ${ }^{32} P$-labeled pKEX-CAT-plasmid. The fragment of $5.8 \mathrm{~kb}$ size is due to crosshybridization of $p K E X-C A T$ to $p S V 2$ neo plasmid. The additional bands of different size in each BL60-pKEX-CAT clone represent integrated pKEX-CAT sequences joined to genomic BL60-P7 sequences. (b) Southern blot analysis of BJA-B and BL60-BC230a transfectants. Lane 1: BJA-B$B C 230 a$ clone 6.6.7.; lane 2: BJA-B-BC230a clone 6.10.2.; lane 3: BJA-B$B C 230 a$ clone 7.2.6.; lane 4: BL60-BC230a clone 6.9.4.; lane 5: BL60BC230a clone 6.7.2.; lane 6: BL60-BC230a clone 6.2.2.; lane 7: BL60-P7. The genomic DNA of BJA-B and BL60-P7-BC230a clones was BamHI digested, blotted and hybridized with the ${ }^{32}$ P-labeled BC230a plasmid. The two bands visible in all clones refer to the 12.7 and $2.0 \mathrm{~kb}$ fragments resulting after BamHI digestion of the episomal BC230a DNA. The 5.8 $k b$ fragment results from cross-hybridization of $B C 230 a$ plasmid with the pSV2neo-plasmid.

fragment, BC-GM-CSF from the EcoRI-cDNA ${ }^{43}$ and BCTNF $\alpha$ from the PstI-TNF $\alpha$ cDNA. ${ }^{42}$

\section{Plasmid preparation}

For transfection, plasmids were amplified in E. coli strain Sure cells (Stratagene), isolated using the Ish Horowitz method $^{40}$ and purified by cesium chloride gradient centrifugation. The DNA was dialysed against $10 \mathrm{~mm}$ Tris, 1 mM EDTA, pH 8 (TE), ethanol-precipitated and resuspended in sterile water.

\section{Cell lines}

BL60-P7 is a neomycin-resistant and hypoxanthine-guanine-phosphoribosyltransferase (HGPRT)-deficient subline of the Burkitt's lymphoma cell line BL60.13 BJA-B is an EBV-negative B cell lymphoma cell line. ${ }^{44}$ Cells were cultured in RPMI-1640 medium (GIBCO Laboratories, Grand Island, NY, USA) supplemented with $10 \%$ heat- 


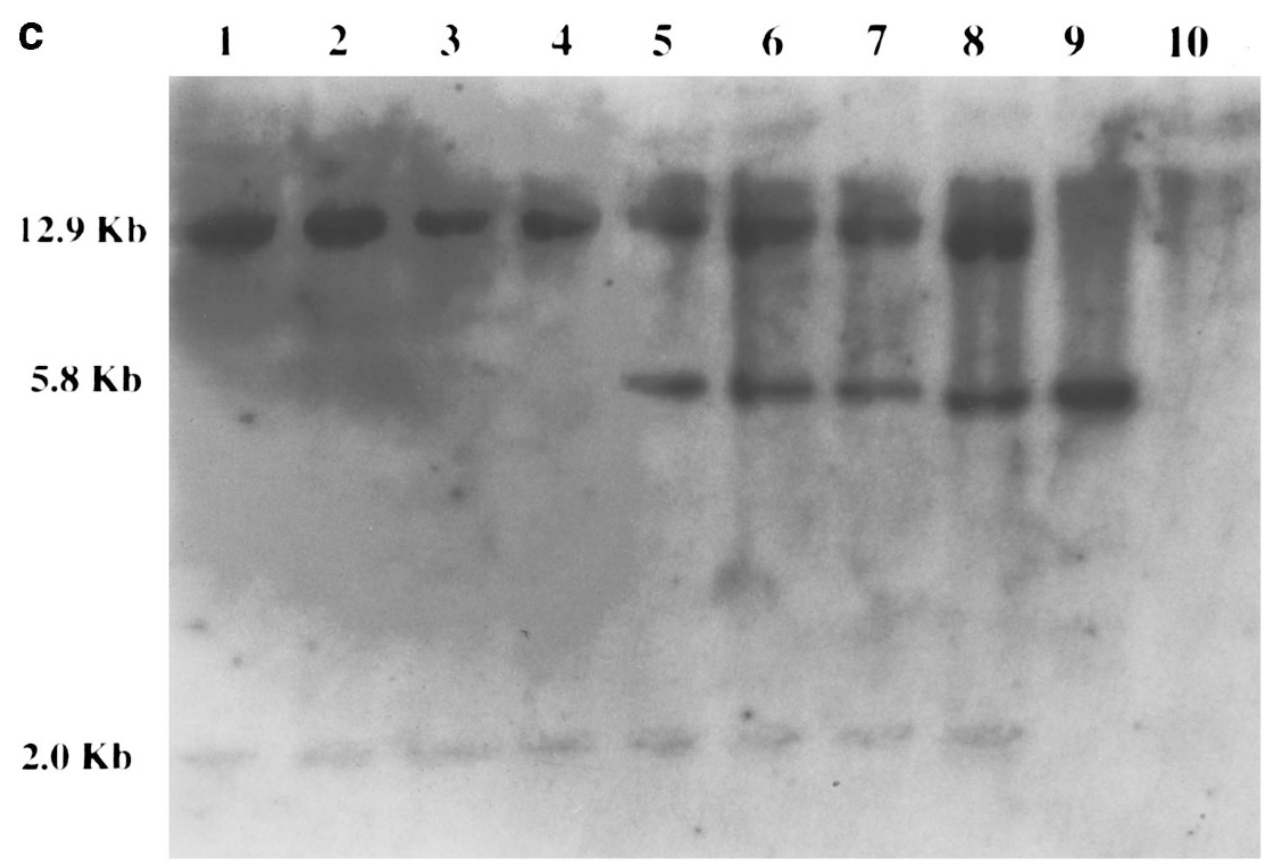

Figure 2 (c) Southern blot analysis of BJA-B and BL60-BC-TNF $\alpha$ transfectants. Lane 1: BJA-B-BC-TNF $\alpha$ clone 6.7.8.; lane 2: BJA-B-BC-TNF $\alpha$ clone 7.1.2. lane 3: BJA-B-BC-TNF $\alpha$ clone 6.2.6.; lane 4: BJA-B-BC-TNF $\alpha$ clone 7.2.1.; lane 5: BL60-BC-TNF $\alpha$ clone 6.9.2.; lane 6: BL60-BC-TNF $\alpha$ clone 7.11.3.; lane 7: BL60-BC-TNF $\alpha$ clone 6.2.7.; lane 8: BL60-BC-TNF $\alpha$ clone 6.7.5.; lane 9: BL60-P7; lane 10: BJA-B. The genomic DNA of BJA-B and BL60-P7-BC-TNF $\alpha$ clones was BamHI digested, blotted and hybridized with the ${ }^{32}$ P-labeled BC219 plasmid. The two fragments detected of 12.9 and $2.0 \mathrm{~kb}$ size represent the BamHI digested BC-TNF $\alpha$ plasmid. The $5.8 \mathrm{~kb}$ fragment in the BL60-BC-TNF $\alpha$ clones is due to cross-hybridization of the BC219 plasmid with pSV2neo-plasmid.

Table 3 Secretion of cytokines and expression of CAT protein in BJA-B and BL60 P7 transfectants

\begin{tabular}{|c|c|c|c|c|}
\hline Cytokine/marker gene & Target cell & Vector & Numbers of clones & Gene expression \\
\hline$C A T$ & BJA-B & $\begin{array}{l}\text { mock } \\
\text { pKEX-CAT } \\
\text { BC230a }\end{array}$ & $\begin{array}{r}1 \\
10 \\
10\end{array}$ & $\begin{array}{l}\text { negative } \\
90-2100 \mathrm{pg} / \mathrm{ml} \\
3800-5200 \mathrm{pg} / \mathrm{ml}\end{array}$ \\
\hline $\mathrm{TNF} \alpha$ & BJA-B & $\begin{array}{l}\text { mock } \\
\text { pKEX-TNF } \\
\text { BC219-TNF }\end{array}$ & $\begin{array}{r}1 \\
9 \\
10\end{array}$ & $\begin{array}{l}\text { negative } \\
40-2050 \mathrm{pg} / \mathrm{ml} \\
500-2100 \mathrm{pg} / \mathrm{ml}\end{array}$ \\
\hline IL6 & BJA-B & $\begin{array}{l}\text { mock } \\
\text { pKEX-IL6 } \\
\text { BC219-IL6 }\end{array}$ & $\begin{array}{r}1 \\
10 \\
10\end{array}$ & $\begin{array}{l}\text { negative } \\
8-700 \mathrm{pg} / \mathrm{ml} \\
900-1250 \mathrm{pg} / \mathrm{ml}\end{array}$ \\
\hline GM-CSF & BJA-B & $\begin{array}{l}\text { mock } \\
\text { BC219-GM-CSF }\end{array}$ & $\begin{array}{r}1 \\
10\end{array}$ & $\begin{array}{l}\text { negative } \\
655-680 \mathrm{pg} / \mathrm{ml}\end{array}$ \\
\hline CAT & BL60 & $\begin{array}{l}\text { mock } \\
\text { pKEX-CAT } \\
\text { BC230a }\end{array}$ & $\begin{array}{r}1 \\
5 \\
10\end{array}$ & $\begin{array}{l}\text { negative } \\
\text { negative } \\
3800-5100 \mathrm{pg} / \mathrm{ml}\end{array}$ \\
\hline $\mathrm{TNF} \alpha$ & BL60 & $\begin{array}{l}\text { mock } \\
\text { pKEX-TNF } \\
\text { BC219-TNF }\end{array}$ & $\begin{array}{r}1 \\
9 \\
10\end{array}$ & $\begin{array}{l}\text { negative } \\
\text { negative } \\
1350-1900 \mathrm{pg} / \mathrm{ml}\end{array}$ \\
\hline IL6 & BL60 & $\begin{array}{l}\text { mock } \\
\text { pKEX-IL6 } \\
\text { BC219-IL6 }\end{array}$ & $\begin{array}{r}1 \\
5 \\
10\end{array}$ & $\begin{array}{l}\text { negative } \\
\text { negative } \\
900-1210 \mathrm{pg} / \mathrm{ml}\end{array}$ \\
\hline GM-CSF & BL60 & $\begin{array}{l}\text { mock } \\
\text { BC219-GM-CSF }\end{array}$ & $\begin{array}{r}1 \\
10\end{array}$ & $\begin{array}{l}\text { negative } \\
650-655 \mathrm{pg} / \mathrm{ml}\end{array}$ \\
\hline
\end{tabular}

The values given represent cytokine concentrations in the supernatant of the most productive and the less productive clone. Each value is a mean of two independent measured values. Measurements were performed using ELISA (Quantikine, Biermann, Germany). 
Table 4 In vitro expression of BL60-BC-IL6 cells with and without hygromycin B selection

\begin{tabular}{lcccccrrrrrr}
\hline & $W_{0}$ & $W_{1}$ & $W_{2}$ & $W_{3}$ & $W_{4}$ & $W_{5}$ & $W_{6}$ & $W_{7}$ & $W_{8}$ & $W_{9}$ \\
\hline IL6 + Hygro & 456.5 & 456.5 & 399.9 & 454.3 & 470.2 & 448.8 & 459.6 & 461.3 & 469.7 & 440.0 \\
IL6 - Hygro & & 444.3 & 358.6 & 367.7 & 222.0 & 52.6 & 71.5 & 69.8 & 17.6 & 12.5 \\
\hline
\end{tabular}

$W_{0}$ : IL6 concentration at the beginning of the experiment; $W_{1}$ : IL6 concentration after 1 week; $W_{9}$ : IL6 concentration after 9 weeks.

Table 5 IL6 expression of BL60-BC-IL6 cells after inoculation in vivo

\begin{tabular}{|c|c|c|c|c|}
\hline $\begin{array}{l}\text { Tumor } \\
\text { size }(\mathrm{mm})\end{array}$ & $\begin{array}{l}\text { t1: IL6 conc. before s.c. } \\
\text { inoculation }(\mathrm{pg} / \mathrm{ml})\end{array}$ & $\begin{array}{l}\text { t2: IL6 conc. after } \\
2 \text { weeks }(\mathrm{pg} / \mathrm{ml})\end{array}$ & $\begin{array}{l}\text { t3: IL6 conc. after } \\
4 \text { weeks }(\mathrm{pg} / \mathrm{ml})\end{array}$ & $\begin{array}{l}\text { t4: IL6 conc. after } \\
6 \text { weeks }(\mathrm{pg} / \mathrm{ml})\end{array}$ \\
\hline $0 \times 0$ & 456.5 & & & \\
\hline $\begin{aligned} 10 & \times 10 \text { right } \\
0 & \times 0 \text { left }\end{aligned}$ & & $\begin{array}{c}212.6 \\
0\end{array}$ & & \\
\hline $\begin{array}{l}20 \times 20 \text { right } \\
20 \times 20 \text { left }\end{array}$ & & & $\begin{array}{r}66.7 \\
133.0\end{array}$ & \\
\hline $\begin{array}{l}25 \times 12 \text { right } \\
30 \times 30 \text { left }\end{array}$ & & & & $\begin{array}{r}118.9 \\
69.8\end{array}$ \\
\hline
\end{tabular}

inactivated fetal calf serum (FCS), $2 \mathrm{~mm}$ glutamine, 100 $\mathrm{IU}$ penicilline and $100 \mu \mathrm{g}$ streptomycin $/ \mathrm{ml}$.

\section{Transfection}

BL60-P7 and BJA-B cells were transfected using the electroporation method. ${ }^{45}$ Briefly, $2 \times 10^{7}$ cells and $20 \mu \mathrm{g}$ DNA in a total volume of $200 \mu$ l PBS were placed in an electroporation chamber with an electrode distance of 4 $\mathrm{mm}$. A high voltage of $200 \mathrm{~V}$ (BJA-B), respectively 220 V (BL60-P7), was applied with an electropulsing device, capacitance 1050 microfarads (Easyject, Eurogentec, Belgium). After $5 \mathrm{~min}$ on ice, $15 \mathrm{ml}$ of growth medium was added, and cells were incubated for $24 \mathrm{~h}$. Then, cells were plated on 96-well microtiter plates at a concentration of $2 \times 10^{5}$ cells / $\mu$ l for selection of hygromycin Bresistant clones (400 $\mu \mathrm{g}$ hygromycin/ml medium). Clones of transfected cells were identified 21 days after transfection and were transferred into 24-well microtiter plates.

\section{Enzyme-linked immunosorbent assay (ELISA)}

Concentrations of human cytokines IL6, TNF $\alpha$ and GMCSF in cell culture supernatants were determined by a commercially available ELISA (Quantikine), distributed by Biermann, Bad Nauheim, Germany. Cells were plated $24 \mathrm{~h}$ before measurement in fresh medium at a concentration of $1 \times 10^{6}$ cells $/ \mu$ l without hygromycin B. ELISA was performed according to the manufacturer's instructions. The sensitivity thresholds were: $0.35 \mathrm{pg} / \mathrm{ml}$ (IL6), $0.17 \mathrm{pg} / \mathrm{ml}(\mathrm{TNF} \alpha)$ and $1.5 \mathrm{pg} / \mathrm{ml}$ (GM-CSF). CAT protein in cell lysates was measured with a CAT-ELISA (Boehringer-Mannheim, Mannheim, Germany) by using $50 \mu \mathrm{g}$ of total protein extract.

\section{Southern blotting}

Extraction of total cellular DNA and restriction endonuclease digestion were performed using standard protocols. ${ }^{40}$ After restriction enzyme digestion $10 \mu \mathrm{g}$ of cleaved a

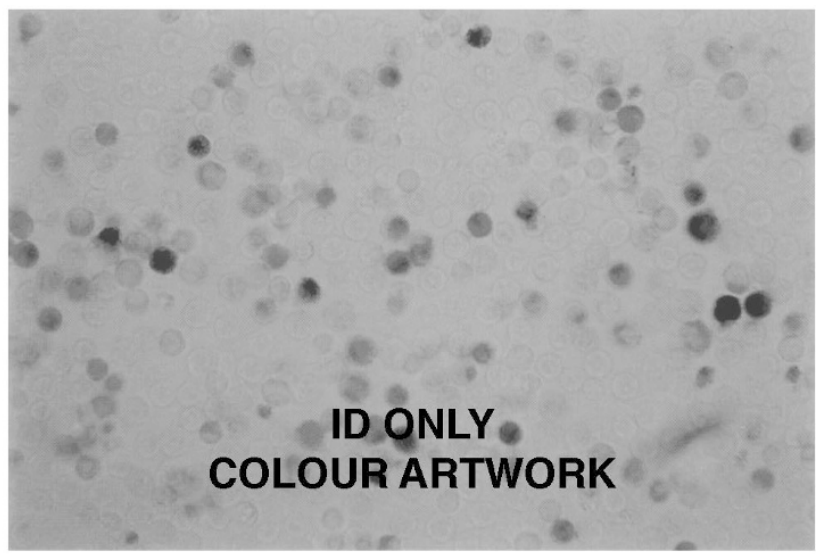

b

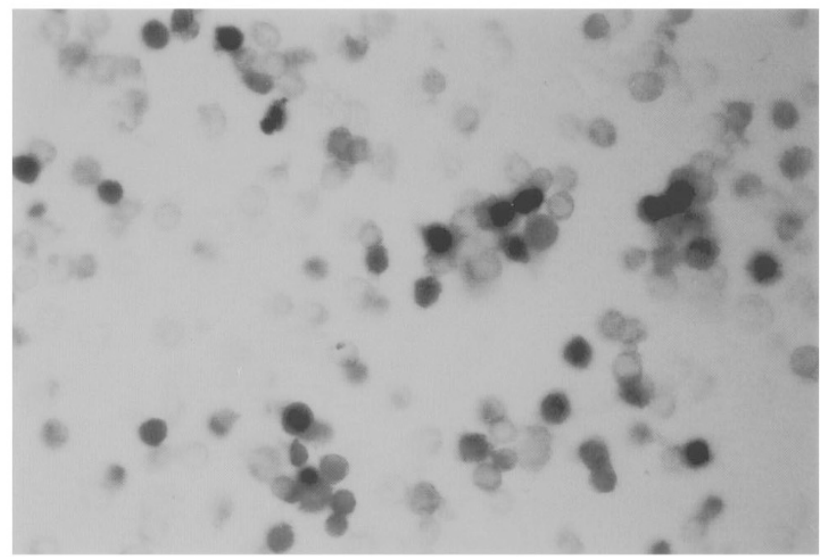

Figure $3 \beta$-Gal assay of BJAB-BC-DZ17 and BL60-BC-DZ17 transfectants. (a) BL60-BC-DZ17 clone 1.3.5.: $50 \%$ of the transfected cells show lacZ expression. (b) BJA-B-BC-DZ17 clone 4.3.5.: $80 \%$ of the transfected cells show lacZ expression. 
cellular DNA were separated by agarose gel electrophoresis and transferred on to a nylon filter (Gene Screen Plus; NEN, Boston, MA, USA). Hybridization was performed in $50 \%$ formamide, $2 \times \mathrm{SSC}$ at $42^{\circ} \mathrm{C}$ with ${ }^{32} \mathrm{P}$-labeled DNA probes. ${ }^{46}$ The following probes were used: the pKEX-CAT (Figure 2a), the BC230a plasmid (Figure 2b) and the BC219 plasmid (Figure 2c).

\section{Tumorigenicity assays}

Untreated, 4-week-old female nu/nu mice (Swiss background, purchased from Charles River, Wilmington, MA, USA) were inoculated with exponentially growing cells (with a viability of at least 90\%). In $0.1 \mathrm{ml}$ RPMI 1640 $1 \times 10^{7}$ cells were suspended and subsequently inoculated under the skin of both flanks of untreated, 4-week-old female $\mathrm{nu} / \mathrm{nu}$ mice. The animals were examined twice weekly and the maximal and minimal diameter of each tumor was measured.

\section{$\beta$-Galactosidase ( $\beta$-gal) assay}

For the $\beta$-gal assay exponentially growing cells were centrifuged, washed once with PBS, resuspended to a concentration of $2 \times 10^{3}$ cells $/ \mu \mathrm{l}$ and transferred on to adhesion slides (Biorad, Munich, Germany). After 10 $\mathrm{min}$, cells were fixed in formaldehyde (3.7\%)-PBS, and incubated with an X-gal solution (0.1 M sodium phosphate buffer, $\mathrm{pH} 7.6$, containing $2.5 \%(\mathrm{v} / \mathrm{v})$ of $40 \mathrm{mg} / \mathrm{ml}$ 5-bromo-4-chloro-3-indolyl- $\beta$-D-galactopyranoside (Stratagene) solution in DMSO, $5 \mathrm{~mm}$ of both potassium ferricyanide and potassium ferrocyanide, $2 \mathrm{~mm} \mathrm{MgCl}_{2}$ at $37^{\circ}$ $\mathrm{C}$ for $2-24 \mathrm{~h}$. The $\beta$-gal reaction was stopped by washing with $0.1 \mathrm{M}$ phosphate buffer.

\section{Acknowledgements}

This work was supported by the Deutsche Forschungsgemeinschaft (DFG, grant No. Di 184/9-5 TP 7) and by the Zentrum für Molekulare Medizin Köln (ZMMK). The authors wish to thank Fa Biermann (Germany) for kindly supporting this work.

\section{References}

1 Watanabe $\mathrm{Y}$ et al. Exogenous expression of mouse interferon $\gamma$ cDNA in mouse neuroblastoma $\mathrm{C} 1300$ cells results in reduced tumorigenicity by augmented antitumor immunity. Proc Natl Acad Sci USA 1989; 86: 9456-9640.

2 Gansbacher B et al. Interleukin-2 gene transfer into tumor cells abrogates tumorigenicity and induces protective immunity. J Exp Med 1990; 172: 1217-1224.

3 Fearon ER et al. Interleukin-2 production by tumor cells bypasses $\mathrm{T}$ helper function in the generation of an antitumor response. Cell 1990; 60: 397-403.

4 Miller AR, McBride WH, Hunt K, Economou JS. Cytokinemediated gene therapy for cancer. Ann Surg Oncol 1994; 1: 436-450.

5 Hock $\mathrm{H}$ et al. Tumor-cell-targeted cytokine gene transfer in experimental models for cancer therapy. Nat Immunol 1994; 13: 85-92.

6 Fujiwara T, Grimm EA, Roth JA. Gene therapeutics and gene therapy for cancer. Curr Opin Oncol 1994; 6: 96-105.

7 Campbell MJ et al. Idiotype vaccination against murine B cell lymphoma: humoral and cellular requirements for the full expression of antitumor immunity. J Immunol 1990; 145: 10291036.

8 Bernstein N, Starnes CO, Levy R. Specific enhancement of the therapeutic effect of anti-idiotypic antibodies on a murine $\mathrm{B}$ cell lymphoma by IL-2. J Immunol 1988; 140: 2839-2843.

9 Tao MH, Levy R. Idiotype/granulocyte-macrophage colony-stimulating factor fusion protein as a vaccine for B-cell lymphoma. Nature 1993; 362: 755-758.

10 Helsop HE. Cytokine gene transfer in the therapy of malignancy. Baillière's Clin Hematol 1994; 7: 135-151.

11 Banerjee S, Livanos E, Vos JMH. Therapeutic gene delivery in human B-lymphoblastoid cells by engineered non-transforming infectious Epstein-Barr virus. Nat Med 1995; 12: 1303-1308.

12 Southern PJ, Berg P. Transformation of mammalian cells to antibiotic resistance with a bacterial gene under control of the SV40 early region promoter. J Mol Appl Genet 1982; 1: 327-341.

13 Wolf J, Pawlita M, Bullerdiek J, zur Hausen H. Suppression of the malignant phenotype in somatic cell hybrids between Burkitt's lymphoma cells and Epstein-Barr virus immortalized lymphoblastoid cells despite deregulated $c-m y c$ gene expression. Cancer Res 1990; 50: 3095-3100.

14 Culver KW, Ram Z, Wallbridge S. In vivo gene transfer with retroviral vector-producer cells for treatment of experimental brain tumors. Science 1992; 256: 1550-1552.

15 Cardoso JE, Branchereau S, Jeyaraj PR. In situ retrovirusmediated gene transfer into dog liver. Hum Gene Ther 1993; 4: 411-418.

16 Li Q, Kay MA, Finegold M. Assessment of recombinant adenoviral vectors for hepatic gene therapy. Hum Gene Ther 1993; 4: 403-409.

17 Russell SW, Miller AD, Alexander IE. Adeno-associated virus vectors preferentially transduce cells in S-phase. Proc Natl Acad Sci USA 1994; 91: 8915-8919.

18 Fink FJ, Sternberg LR, Weber PC. In vivo expression of $\beta$-galactosidase in hippocampal neurons by HSV-mediated gene transfer. Hum Gene Ther 1992; 3: 11-19.

19 Moss B, Flexner C. Vaccinia virus expression vectors. Annu Rev Immunol 1987; 5: 305-324.

20 Miller AD. Human gene therapy comes of age. Nature 1992; 357: 455-460.

21 Anderson WF. Human gene therapy. Science 1992; 256: 808-813.

22 Yang R, Nunes FA, Berencsi K. Cellular immunity to vital antigens limits E1-deleted adenoviruses for gene therapy. Proc Natl Acad Sci USA 1994; 91: 4407-4411.

23 Dubensky TW, Campbell BA, Villareal LP. Direct transfection of viral and plasmid DNA into the liver or spleen of mice. Proc Natl Acad Sci USA 1984; 81: 7529-7533.

24 Wolff JA, Malone R, Williams P. Direct gene transfer into mouse muscle in vivo. Science 1990; 247: 1465-1468.

25 Felgner PL, Ringold GM. Cationic liposome-mediated transfection. Nature 1989; 337: 387-388.

26 Perales JC, Ferkol T, Beegen H. Gene transfer in vivo: sustained expression and regulation of genes introduced into the liver by receptor-targeted uptake. Proc Natl Acad Sci USA 1994; 91: 4084-4090.

$27 \mathrm{Wu} \mathrm{GY}, \mathrm{Wu} \mathrm{CH}$. Receptor-mediated gene delivery and expression in vivo. J Biol Chem 1988; 263: 14621-14624.

28 Middleton T, Sugden B. Retention of plasmid DNA in mammalian cells is enhanced by binding of the Epstein-Barr virus replication protein EBNA1. J Virol 1994; 68: 4067-4071.

29 Rittner K, Stöppler H, Pawlita M, Sczakiel G. Versatile eucaryotic vectors for strong and constitutive transient and stable gene expression. Meth Mol Cell Biol 1991; 2: 176-181.

30 Oehm A et al. Purification and molecular cloning of the APO-1 cell surface antigen, a member of the tumor necrosis factor/nerve growth factor receptor superfamily. J Biol Chem 1992; 267: 10709-10715.

31 Kischkel FC et al. Cytotoxicity-dependent APO-1 (Fas/CD95)associated proteins form a death-inducing signaling complex (DISC) with the receptor. EMBO J 1995; 14: 5579-5588.

32 Diehl V, Henle G, Henle W, Kohn G. Demonstration of a Herpes group virus (EBV) in cultures of peripheral leucocytes from patients with infectious mononucleosis. J Virol 1968; 2: 366-371.

33 Raab-Traub N. Epstein-Barr virus and nasopharyngeal carcinoma. Semin Cancer Biol 1992; 3: 297-307.

34 Jones JF et al. T-cell lymphomas containing Epstein-Barr viral 
DNA in patients with chronic Epstein-Barr virus infection. New Engl J Med 1988; 318: 733-738.

35 Wolf $\mathrm{H}$, Haus M, Wilmes E. Persistence of Epstein-Barr virus in the parotid gland. J Virol 1984; 51: 795-801.

36 Greenspan JS et al. Replication of Epstein-Barr virus within the epithelial cells of oral 'hairy' leukoplakia, and AIDS-associated lesion. New Engl J Med 1985; 313: 1564-1569.

37 Lee ES et al. The association of Epstein-Barr virus with smoothmuscle tumors occurring after organ transplantation. New Engl J Med 1995; 332: 19-25.

38 Polack A, Eick D, Koch E, Bornkamm GW. Truncation does not abrogate transcriptional downregulation of the $c-m y c$ gene by sodium butyrate in Burkitt's lymphoma cells. EMBO J 1987; 6: 2959-2964.

39 Polack A, Feederle R, Klobeck G, Hörtnagel K. Regulatory elements in the immunoglobulin kappa locus induce $c-m y c$ activation and the promoter shift in Burkitt's lymphoma cells. EMBO J 1993; 12: 3913-3920.

40 Sambrook J, Fritsch EF, Maniatis T. Molecular Cloning: A Laboratory Manual. Cold Spring Harbor Laboratory: Cold Spring Harbor, NY, 1989.
41 Zilberstein A, Ruggieri R, Korn JH, Revel M. Structure and expression of cDNA and genes for human interferon-beta-2, a distinct species inducible by growth-stimulatory cytokines. EMBO J 1986; 5: 2529-2537.

42 Wang AM et al. Molecular cloning of the complementary DNA for human tumor necrosis factor. Science 1985; 228: 149-153.

43 Wong GG et al. Human GM-CSF: molecular cloning of the complementary DNA and purification of the natural and recombinant proteins. Science 1985; 228: 810-815.

44 Menezes J, Leibold G, Klein G, Clements G. Establishment and characterization of an Epstein-Barr virus (EBV)-negative lymphoblastoid cell line (BJA-B) from an exceptional, EBV-genome negative African Burkitt's lymphoma. Biomedicine 1975; 22 : 276-284.

45 Potter H, Weir L, Leder P. Enhancer-dependent expression of human $\mathrm{k}$ immunoglobulin genes introduced into mouse pre-B lymphocytes by electroporation. Proc Natl Acad Sci USA 1984; 81: 7161-7165.

46 Feinberg A, Vogelstein B. A technique for radiolabeling DNA restriction endonuclease fragments to high specific activity. Anal Biochem 1994; 137: 266-270. 